\title{
Educational and Informational Space of the Educational Establishment as a Pedagogical Condition for the Formation of Students' Social Activity
}

\author{
Bulavenko Svitlana \\ ORCID 0000-0001-9732-6645 \\ PhD applicant, Doctoral student \\ Institute of Problems on Education \\ National Academy of Educational Sciences of Ukraine (Kyiv, Ukraine)
}

\begin{abstract}
The article describes the features of the educational and informational space of educational institutions for the formation of students' social activity. Analysis of scientific literature made it possible to clarify the essence of the concept of "educational and informational space" for the formation of social activity of students as a pedagogically expediently organized space of life, which contributes to the development of a socially active person; an integrated means of accumulation and realization of educational, developing and socializing potential of institutions of general secondary education. The features of a specially organized educational and informational space for the formation of social activity of the individual in educational institutions in the article are considered through the participation of students in social activities, in particular, in children's associations.

The social space of a socially oriented children's association is considered in the composition of three subsystems, which also changes the social role of the child, and the nature of his activity: interpersonal interaction of the educational environment of the children's association, in which the child acts as a participant in the educational process; the social environment of a children's association, representing the space of creative self-expression and self-realization, in which the child acts as the subject of his creativity and education; an external socializing space in which the child acts as a citizen of a society.

Formation of social activity of students in the article is considered on the example of children's associations created in the experimental educational institutions of Chernihiv region "Erudit", "Euroclub", "Traveler's Club", "Jura", "Ecopatral", "Volunteer". The ideas underlying this experience are the formation of active life positions in students, an indifferent attitude to the environment and society, the comprehensive development of the individual as a result: the organization of the interaction of children's associations in experimental educational institutions with the aim of creating a space of social interaction for the development of social activity of children and young people; creation of a unified database of methodological materials on the organization of activity of children's associations on the basis of schools, necessary for use in practical work; creation of the necessary conditions for constructive dialogue, network interaction between educational institutions and children's associations on issues related to the organization of joint activities on relevant areas of work for the exchange of experience through the organization of seminars and roundtables; creation of in-school children's children's associations.
\end{abstract}

Key words: education and information space, pedagogical condition, social activity of pupils, children's associations, establishments of general secondary education.

Актуальність дослідження. На сучасному етапі суспільного розвитку суттєво розширився соціальний простір, у якому проходить життєдіяльність людини. Поза активним включенням людини в багатоманітні відносини в процесі діяльності, яка ускладнюється, з установкою на «зміни оточуючої дійсності з позиції перетворюючої 
участі» [15, с. 35] повноцінний соціальний розвиток сучасної людини є неможливим. Таким чином, основою таких якостей, як колективізм, підприємливість, конкурентоспроможність є соціальна активність. Соціальна активність виступає умовою самовизначення особистості в суспільстві і свідомої регуляції поведінки; проявляється в різних сферах життєдіяльності людини: трудовій, громадськополітичній, освітньо-дозвіллєвій, соціально-побутовій. Вона реалізується в різних формах не лише як індивідуальна, а й як групова чи колективна, спрямована на реалізацію можливостей та потенціалу тих чи інших соціальних груп $[9$, с. 64; 18; 19 ; $20]$.

У контексті формування соціально активної особистості особливого значення набуває проблема створення освітньо-інформаційного простору в закладах загальної середньої освіти (З3СО).

Особливості формування соціально активної особистості знайшли відображення в дослідженнях І. Беха [2; 3], Л. Канішевської [9; 10;11; 12; 14; 26], І. Гавриш [6], Т. Мальковської [15], Л. Петько [16; 18], В. Рахманова [22] та ін.

Проте, не зважаючи на широке відображення проблеми в спеціальній літературі, питання створення освітньо-інформаційного простору для формування соціальної активності учнів не достатньо висвітлено в наукових дослідженнях.

Mema cmammi - розкрити одну із педагогічних умов формування соціальної активності в учнів закладів загальної середньої освіти, а саме - створення освітньоінформаційного простору закладу освіти.

Виклад основного матеріалу. Під освітньо-інформаційним простором закладів загальної середньої освіти О. Разуменко [21], В. Рахманов [22], Н. Рибка [23], А. Цимбалару [25] та ін. розуміють сукупність соціальних, культурних і спеціальних (змодельованих) психолого-педагогічних умов для «вирощування» особистісних якостей учнів, сформованих при адекватному використанні можливостей інформаційного ресурсу й «максимальної віддачі» всіх компонентів інформаційної моделі освітнього процесу закладу загальної середньої освіти [22].

Теоретичний аналіз наукової літератури з проблеми дослідження дозволив нам уточнити сутність поняття «освітньо-інформаційний простір» для формування соціальної активності учнів, як педагогічно доцільний організований простір 
життєдіяльності, який сприяє розвитку соціально активної особистості; є інтегрованим засобом накопичення й реалізації освітнього, розвиваючого та соціалізуючого потенціалу закладів загальної середньої освіти [4].

Освітньо-інформаційний простір на рівні закладу загальної середньої освіти забезпечує обмін потоками інформації та взаємодію між усіма учасниками освітнього процесу всередині 33СО, а також обмін інформацією та взаємодію 3 зовнішніми структурами - освітніми установами, бібліотеками, навчальними й інформаційними центрами та іншими організаціями [4].

Особливості спеціально організованого освітньо-інформаційного простору для формування соціальної активності особистості в закладах освіти розглянемо через призму участі школярів в соціальній діяльності, зокрема, в дитячих об'єднаннях. Саме завдяки залученню до конструктивної діяльності в дитячому колективі учні набувають первинного досвіду взаємодії в соціумі [14]. При цьому цілі діяльності дитячих об’єднань представляють собою поєднання цілей дітей і виховних цілей дорослих; опосередкованість виховання через колективну діяльність, систему ділової та міжособистісної взаємодії як компонент корпоративної культури організації; специфіка суб'єктів виховання в дитячих об'єднаннях визначає характер керівництва нею на основі педагогічного супроводу організації дітей [24].

Саме ці особливості розкривають виховні можливості дитячих об'єднань. Соціальний простір соціально спрямованого дитячого об'єднання розглядаємо в складі наступних трьох підсистем, в яких змінюється й соціальна роль дитини, і характер їі діяльності:

- міжособистісна взаємодія виховного середовища дитячого об'єднання, в якому дитина виступає в ролі учасника виховного процесу. Можливість реалізації форм соціального виховання дітей, в яких інтегрується процес розвитку особистості засобами навчання, виховання, соціалізації, самовиховання, самоосвіти, сприяє формуванню особистісно значущих цінностей, розвитку соціальної активності дитини, її суб'єктної позиції;

- суспільне середовище дитячого об’єднання, що представляє собою простір творчого самовираження й самореалізації, в якому дитина виступає в ролі суб'єкта своєї творчості й виховання. Таке середовище надає дитині можливість отримати 
особистий життєвий досвід самостійності, спілкування, уміння працювати в команді, колективної спільної діяльності з однолітками, виступає засобом емоційного розвитку в колі товаришів, однодумців;

- зовнішній соціалізаційний простір, в якому дитина виступає в ролі громадянина суспільства. Розумно організована спільна діяльність дітей за підтримки дорослих в середовищі їх життєдіяльності, соціум, в якому дитина реально може проявити себе як суб'єкт діяльності в різних статусах, ролях, позиціях, в індивідуальній та колективній, виконавчій і творчій діяльності як особистість зі своєю громадянською позицією допомагає їй отримати досвід залучення до майбутніх державних i громадських структур [8].

Дослідники виховного потенціалу дитячих об'єднань [1; 5; 6; 7; 8; 14; 24] підкреслюють соціальну сутність дитячої організації, яка включає дітей в широкий спектр суспільних відносин, що виводить їх на освоєння певних соціальних ролей, норм, позицій; загальну спрямованість діяльності дитячої організації, в якій реалізуються найважливіші потреби дітей, що відображають їх прагнення до дорослості; самодіяльний характер життєдіяльності дітей в організації, що передбачає саморозвиток особистості; суб’єкт-суб'єктний характер відносин в дитячій організації, що передбачає реалізацію виховних функцій в системі взаємодії дітей один з одним [4].

На думку Н. Коляди, в дитячому об’єднанні виховна функція реалізується за допомогою визначення прав і обов'язків, як дітей, так і дорослих його членів. При цьому права виступають в ролі норм поведінки, які регулюють життєдіяльність та взаємовідносини між членами об'єднання. Свобода, в даному контексті, виступає як право вибору виду діяльності й норм вираження ставлення до своїх друзів, колективу, оточуючих людей. [14]. А обов’язки, в цьому випадку - певні моральні вимоги до всіх членів організації, які виступають як обов'язок кожного. Вони характеризують вимоги й відносяться до всіх членів об'єднання без винятку [8].

У процесі дослідно-експериментальної роботи у закладах освіти Чернігівської області (Комунального закладу загальної середньої освіти I-III ступеня «Варвинський ліцей № 2»; Михайло-Коцюбинської гімназії; Ніжинських гімназіях № 2 та № 3; Ніжинської загальноосвітньої школи № 11; Срібнянської загальноосвітньої школи; загальноосвітніх шкіл у м. Чернігові № 3 та № 19) були створені дитячі об’єднання 
соціального спрямування, які взаємодіяли між собою і громадськими організаціями населених пунктів. У дитячих об’єднаннях, створених на базі закладів загальної середньої освіти на сьогодні накопичено певний досвід організації виховного простору, сформованого в результаті цілеспрямованих педагогічних зусиль в організації спільної суспільно значущої діяльності дітей та учнівської молоді. Прикладами такого досвіду $є$ внутрішньошкільні дитячі об’єднання: «Ерудит», «Євроклуб», «Клуб мандрівників», «Джура», «Екопатруль», «Волонтер».

Так, учасники інтелектуального об’єднання «Ерудит» неодноразово змагалися в брейн-рингах, віртуальних вікторинах, квестах. Налагоджена діяльність міжшкільного «Свроклубу», учасники якого мали змогу відвідати Хорватію, активно спілкуються із учнями школи невеликого угорського містечка Дьондьош, беруть участь у міжнародних конкурсах, створюють соціальні проекти іноземними мовами (англійською та німецькою).

Щоб допомогти учням в опануванні іноземними мовами, при закладах освіти створено пришкільні літні табори, в яких учні, за участі іноземних волонтерів, як носіїв мови, набувають соціального досвіду та формують комунікативні вміння.

«Клуб мандрівників» об’єднує туристів закладів загальної середньої освіти. Так, учні експериментальних шкіл м. Ніжина здійснили спільний піший похід від витоку річки Остер до м. Ніжин; вони стали постійними учасниками туристичних змагань; влітку учні експериментальних закладів освіти, створивши дві групи, подорожували на байдарках по річках Снов та Удай.

Учасники дитячого об’єднання «Джура» мають досвід співпраці 3 різними навчальними закладами та громадською організацією «Чернігівське земляцтво». Змагання на кшталт «Козацькі розваги» є традиційними. Окрім того, з ініціативи учнівучасників «Джури», в Ніжинській гімназії № 3 відкрили пришкільний літній табір військово-патріотичного спрямування, в якому діти мають змогу спробувати себе в ролі курсантів військових закладів освіти. Постійними гостями віртуального тиру в гімназії (єдиного в області) є учні різних шкіл Чернігівської області. Тож учасники «Джури» часто виступають в ролі інструкторів зі стрільби.

Організаторами багатьох загальноміських та загальношкільних екологічних акцій $\epsilon$ учасники дитячого об’єднання «Екопатруль». 3 метою привернення уваги 
громадськості до екологічних проблем вони влаштувують загальноміські конкурси малюнку «SOS! Планета Земля!», конкурси соціальних проектів «Збережемо тепло!», «Домашній улюбленець в біді!».

Учасники дитячого об’єднання «Екопатруль» звернулися до міської влади 3 проханням облаштувати притулки для тварин, допомагали в облаштуванні трьох екостежок в регіональному ландшафтному парку «Ніжинський», на яких також проводили наукові дослідження тощо.

Ініціаторами благодійних акцій та соціальних проектів постійно виступають учасники дитячого об'єднання «Волонтер». Учні аналогічних об’єднань 3 інших закладів загальної середньої освіти часто співпрацюють для вирішення питань допомоги в лікуванні учнів чи інших людей, допомоги нужденним, воїнам АТО тощо. Об'єднуючи зусилля вони досягають вражаючих результатів. Так, за їх ініціативи було куплено 3 тепловізора, 12 бронежилетів, надано грошову допомогу багатьом онкохворим та погорільцям, малозабезпеченим сім'ям тощо. У соціальних мережах вони створили групу «Ми допоможемо», де розміщують відповідну інформацію.

Ідеї, покладені в основу цього досвіду - це формування в учнів активної життєвої позиції, небайдужого ставлення до оточуючого середовища й соціуму, всебічний розвиток особистості в результаті: організації взаємодії дитячих об'єднань експериментальних $33 \mathrm{CO}$ з метою створення простору соціальної взаємодії для розвитку соціальної активності дітей та молоді; створення єдиної бази методичних матеріалів з організації діяльності дитячих об’єднань на базі 33СО, необхідних для використання в практичній роботі; створення необхідних умов для побудови конструктивного діалогу, мережевої взаємодії між освітніми установами та дитячими об’єднаннями 3 питань, пов’язаних з організацією спільної діяльності з актуальних напрямів роботи з метою обміну досвідом шляхом організації семінарів і круглих столів; створення внутрішньошкільних дочірних дитячих об’єднань.

Висновки. Отже, створення освітньо-інформаційного простору закладу освіти $є$ однією 3 основних умов для формування соціальної активності учнів. Дитячі об'єднання, як складова цього простору, за умови організації роботи з урахуванням інтересів і пріоритетів спільної діяльності та збереження традицій З3СО у поєднанні 3 інноваційними технологіями, можуть виступати фактором розвитку соціальної 
активності особистості.

Аналіз проблеми формування соціальної активності учнів 33СО потребує подальшого й різнопланового дослідження, зокрема, теоретичного обгрунтування та експериментальної перевірки педагогічних умов формування соціальної активності учнів закладів загальної середньої освіти.

\section{References}

1. Bezpalko O. V. Sotsialna pedagogika $v$ shemah $i$ tablitsyah: navchalniy posibnik.Kyiv: tsentr navchalnoyi literaturi, 2003. 134 p.

2. Beh I. D. Osobistist u prostori duhovnogo rozvitku : navch. posib. Kyiv : Akademvidav, 2012. 256 p.

3. Beh I. D. Osobistist u konteksti orientiriv rozvivalnogo navchannya. Innovatika u vihovanni. Vol.1, 2015. P. 7-13.

4. Bulavenko S. D. Osvitno-informatsiyniy prostIr dlya formuvannya sotsialnoaktivnoyi osobistosti: navch.-metod. posIb. Nizhin: PP Lisenko, 2019. 314 p.

5. Volohov A. V. Sotsializatsiya rebenka $v$ detskih obschestvennyih organizatsiyah (voprosyi teorii i metodiki): monografiya. Yaroslav1, 1999. $270 \mathrm{p}$.

6. Gavrish I. I. Stanovlennya sotsialnoyi aktivnosti shkolyariv pid chas vklyuchennya u $\begin{array}{llll}\text { dobrodiynu diyalnist. } & \text { [Elektronniy } & \text { resurs]. } & 2016 .\end{array}$ file://C:/Users/Valeriy/Desktop/Havrysh.pdf

7. Grabovska S., Choliy S. Sotsialna aktivnist v protsesi sotsializatsiyi osobistosti : zb. nauk. pr. In-tu psihologiyi Im. G. S. Kostyuka APN Ukrayini / za red. S. D. Maksimenka. Kyiv, 2010. Vol. XII. Part 1. P. 171-181.

8. Dityachi ob'ednannya Ukrayini u vimIrah minulogo ta suchasnogo: dovidnikposibnik. Lugansk: Alma-Mater, 2006. 256 p.

9. Kanishevska L. V. Vihovannya sotsialnoyi zrilosti starshoklasnikiv zagalnoosvitnih shkil-internativ u pozaurochniy diyalnosti : monografIya. Kyiv, 2011. 368 p.

10. Kanishevska L. V. Sotsializatsiia ta osoblyvosti yii proiavu u vykhovantsiv zahalnoosvitnikh shkil-internativ [Socialization and peculiarities of its manifestation among pupils of general boarding schools] Teoretychni pytannia kultury, osvity ta vykhovannia : zb. nauk. prats Issue 46. Kyiv: Vyd. tsentr KNLU, 2012. P. 57-61.

11. Kanishevska L. V. Doslidzhennia problemy pidhotovky starshoklasnykiv shkilinternativ do samostiinoho zhyttia. [The research of the problem of preparing senior students of orphan boarding schools to their own life] Teoretyko-metodychni problemy vykhovannia ditei ta uchnivskoi molodi: zb. nauk. prats. Kirovohrad: Imeks - LTD, 2013. Issue 17. Book 1. P. 293-299.

12. Kanishevska L.V. Vzaiemodiia pedahohiv $i$ vykhovantsiv na osnovi pedahohichnoi pidtrymky yak umova vykhovannia sotsialnoi zrilosti starshoklasnykiv shkilinternativ [Interaction of teachers and pupils on the basis of pedagogical support as a 
condition for the education of social maturity of senior pupils of boarding schools] Teoretykometodychni problemy vykhovannia ditei ta uchnivskoi molodi : zb. nauk. prats. Issue 13. Book 1. Kamianets-Podilskyi : Vydavets Zvoleiko D. H. 2009. P. 369-379.

13. Kanishevska L. V. Doslidzhennia problemy vykhovannia sotsialnoi zrilosti starshoklasnykiv shkil-internativ. [The research of the problem of fostering social maturity in senior students of orphan boarding schools] Pedahohichnyi almanakh : zb. nauk. prats. Kherson KVNZ "Khersonska akademiia neperervnoi osvity", 2012. Issue 16. P. 213-220.

14. Kolyada N. M. Dityachiy ruh yak institut sotsializatsiyi ditey ta pidlitkiv [The Children's Movement as an Institute for the Socialization of Children and Adolescents] // Sotsializatsiya osobistosti: zb. materialiv Vseukr. nauk.-prakt. konf. (Kyiv, gruden 2008 r.). Kyiv. 2009. P. 179-187.

15. Malkovskaya T. N. Sotsialnaya aktivnost starsheklassnikov [Social activity of secondary school students]: (Pedagogicheskaya nauka - reforme shkolyi). Moscva: Pedagogika, 1988. 144 p.

16. Petko L. V. Derzhavniy standart pochatkovoii osviti u rakursi formuvannya sotsialnoyi aktivnosti ditini [The State Standard for elementary education in the views of social activity formation in a child]. Naukovi zapiski Berdyanskogo derzh. ped. un-tu. Seriya : Pedagogika : zb. nauk. prats. Berdyansk : BDPU, 2018. Vol. 1. P. 92-97.

17. Petko L. V. Pedagogichna sutnist u viznachenni ponyattya «osvitne seredovische» [The pedagogical essence in defining the concept of "educational environment"]. Gumanitarniy visnik DVNZ «Pereyaslav-Hmelnitskiy derzhavniy pedagogichniy universitet imeni Grigoriya Skovorodi»: zb. nauk. prats. - Pereyaslav-Hmelnitskiy, 2014. Vol. 34. P. 109-118.

18. Pet ko L. V. Pidlitky i turyzm [Teenagers and tourism]. Rad. shkola. Kyiv. 1989. No. 2. P. $35-40$.

19. Pet ko L. V. Tury zm - sprava zaxoplyuyucha [Tourism is a fascinating matter]. Rad. shkola. 1990. No. 11. P. 25-29.

20. Pet ko L. V., Verezij V. F. Pidlitok u riznovikovomu zagoni [Teenager in different age group]. Rad. shkola. Kyiv. 1989. No. 11. P. 6-12.

21. Razumenko O. Osvitniy prostir yak mistse rozgortannya pedagogichnih vidnosin [Educational space as a place of development of pedagogical relations.]. 2013. URI: file:///C:/Users/Valeriy/Downloads/29188-53548-1-SM.pdf

22. Rahmanov V. O. Vikoristannya osvitno-informatsiynogo seredovischa u protsesi vivchennya gumanitarnih distsiplin [Use of educational and information environment in the process of studying the humanities]. Visnik Natsionalnogo aviatsiynogo universitetu. Seriya: Pedagogika, psihologiya, 2014. No. 5. P. 25-29.

23. Ribka N. M. Ediniy osvitniy prostir yak integrativna sistema: sotsialno-filosofskiy analiz [The unified educational space as an integrative system: socio-philosophical analysis]: avtoref. dis. ... kand. filos. nauk: 09.00.03. Odesa, 2005. 24 p. 
24. Trotsko G. M., Trubavina I. M., Hlebnikova T. M. Ukrayinski dityachi ta molodizhni gromadski organizatsiyi [Ukrainian children and youth organizations]: navchalniy posibnik. Kharkiv, 1999. 206 p.

25. Tsimbalaru A. D. Osvitniy prostir: sutnist, struktura i mehanizmi stvorennya [Educational space: essence, structure and mechanisms of creation]. Ukrayinskiy pedagogichniy zhurnal. 2016. No 1. P. 41-50.

16. Kanishevska L. V., Stadnik N. V. Theoretical aspects of the concept "responsibility" in works by foreign researchers. Perspectives of research and development: Collection of scientific articles. SAUL Publishing Ltd, Dublin, Ireland, 2017. P. 129-131.

Translation of the Title, Abstract and References to the Author's Language

\section{УДК 37.01.33}

Булавенко Світлана Дмитрівна. Освітньо-інформаційний простір закладу освіти як педагогічна умова формування соціальної активності учнів.

У статті розглядаються особливості освітньо-інформаційного простору закладів освіти для формування соціальної активності учнів. Уточнено сутність освітньоінформаційного простору для формування соціальної активності учнів та основні його характеристики. Особливості спеціально організованого освітньо-інформаційного простору для формування соціальної активності особистості в закладах освіти у статті розглянуто через участь школярів у дитячих об'єднаннях. Визначено, що дитячі об'єднання сприяють формуванню в учнів активної життєвої позиції, небайдужого ставлення до оточуючого середовища й соціуму. В освітньо-інформаційному просторі формування соціальної активності учнів можливе завдяки: організації взаємодії дитячих об'єднань експериментальних закладів освіти; створення єдиної бази методичних матеріалів з організації діяльності дитячих об’єднань на базі шкіл, необхідних для використання в практичній роботі; створення необхідних умов для побудови конструктивного діалогу, мережевої взаємодії між освітніми установами та дитячими об'єднаннями 3 питань, пов'язаних 3 організацією спільної діяльності 3 актуальних напрямів роботи 3 метою обміну досвідом шляхом організації семінарів $\mathrm{i}$ круглих столів; створення внутрішньошкільних дочірних дитячих об’єднань.

Ключові слова: освітньо-інформаційний простір, педагогічні умови, формування соціальної активності учнів, дитячі об’єднання, заклади загальної середньої освіти.

\section{Лimepamypa}

1. Безпалько О. В. Соціальна педагогіка в схемах і таблицях: навчальний посібник. Київ: Центр навчальної літератури, 2003. 134 с.

2. Бех І. Д. Особистість у просторі духовного розвитку: навч. посіб. Київ : Академвидав, 2012. 256 с.

3. Бех І. Д. Особистість у контексті орієнтирів розвивального навчання Інноватика у вихованні. 2015. Вип.1. С. 7-13. 
4. Булавенко С. Д. Освітньо-інформаційний простір для формування соціальноактивної особистості: навч.-метод. посіб. Ніжин: ПП Лисенко, 2019. 314 с.

5. Волохов А. В. Социализация ребенка в детских общественных организациях (вопросы теории и методики): монография. Ярославль, 1999. 270 с.

6. Гавриш I. I. Становлення соціальної активності школярів під час включення у добродійну діяльність [Електронний ресурс]. $2016 . \quad$ URI: file://C:/Users/Valeriy/Desktop/Havrysh.pdf

7. Грабовська С., Чолій С. Соціальна активність в процесі соціалізації особистості : зб. наук. пр. Ін-ту психології ім. Г. С. Костюка АПН України / за ред. С. Д. Максименка. Київ, 2010. Т. ХІІ. Ч. 1. С. 171-181.

8. Дитячі об’єднання України у вимірах минулого та сучасного: довідникпосібник. Луганськ: Альма-Матер, 2006. 256 с.

9. Канішевська Л. В. Виховання соціальної зрілості старшокласників загальноосвітніх шкіл-інтернатів у позаурочній діяльності : монографія. Київ : ХмЦНП, $2011.368 \mathrm{c}$.

10. Канішевська Л.В. Соціалізація та особливості іï прояву у вихованців загальноосвітніх шкіл-інтернатів. Теоретичні питання культури, освіти та виховання: зб. наук. пр. Вип. 46. Київ : Вид. центр КНЛУ, 2012. С. 57-61.

11. Канішевська Л. В. Дослідження проблеми підготовки старшокласників шкілінтернатів до самостійного життя. Теоретико-методичні проблеми виховання дітей та учнівської молоді: зб. наук. пр. Кіровоград : Імекс - ЛТД, 2013. Вип. 17. Кн. 1 С. 293299.

12. Канішевська Л. В. Взаємодія педагогів і вихованців на основі педагогічної підтримки як умова виховання соціальної зрілості старшокласників шкіл-інтернатів. Теоретико-методичні проблеми виховання дітей та учнівської молоді: зб. наук. пр. Кам'янець-Подільський : Видавець Зволейко Д. Г., 2009. Вип. 13. Кн. 1. С. 369-379.

13. Канішевська Л. В. Дослідження проблеми виховання соціальної зрілості старшокласників шкіл-інтернатів. Педагогічний альманах : зб. наук. пр. Херсон КВНЗ «Херсонська академія неперервної освіти», 2012. Вип. 16. С. 213-220.

14. Коляда Н. М. Дитячий рух як інститут соціалізації дітей та підлітків // Соціалізація особистості: зб. матеріалів Всеукр. наук.-практ. конф. (Київ, грудень 2008 р.). Київ, 2009. С. 179-187.

15. Мальковская Т. Н. Социальная активность старшеклассников: (Педагогическая наука - реформе школы). Москва: Педагогика, 1988. 144 с.

16. Петько Л. В. Державний стандарт початкової освіти у ракурсі формування соціальної активності дитини. Наукові записки Бердянського державного педагогічного університету. Серія : Педагогіка : зб. наук. праць. Бердянськ : БДПУ, 2018. Вип. 1. С. 92-97.

17. Петько Л. В. Педагогічна сутність у визначенні поняття «освітнє середовище». Гуманітарний вісник ДВНЗ «Переяслав-Хмельницький державний педагогічний університет імені Григорія Сковороди»: збірник наукових праць. - 
Переяслав-Хмельницький, 2014. Вип. 34. С. 109- 118.

18. Петько Л. В. Підлітки і туризм. Рад. школа. 1989. № 2. С. 35-40.

19. Петько Л В. Туризм - справа захоплююча. Рад. школа. 1990. № 11. С. 25-29.

20. Петько Л. В., Верезій В. Ф. Підліток у різновіковому загоні. Рад. школа. Київ. 1989. № 11. С. 6-12.

21. Разуменко О. Освітній простір як місце розгортання педагогічних відносин. 2013. URI: file:///C:/Users/Valeriy/Downloads/29188-53548-1-SM.pdf

22. Рахманов В. О. Використання освітньо-інформаційного середовища у процесі вивчення гуманітарних дисциплін. Вісник Національного авіаційного університету. Серія: Педагогіка, психологія, 2014. № 5. С. 25-29.

23. Рибка Н. М. Єдиний освітній простір як інтегративна система: соціальнофілософський аналіз: автореф. дис. ... канд. філос. наук: 09.00.03. Одеса, 2005. 24 с

24. Троцко Г. М., Трубавіна I. М., Хлебникова Т. М. Українські дитячі та молодіжні громадські організації: навчальний посібник. Харків, 1999. 206 с.

25. Цимбалару А. Д. Освітній простір: сутність, структура і механізми створення. Украӥнський педагогічний журнал. 2016. № 1. С. 41-50.

26. Kanishevska L. V., Stadnik N. V. Theoretical aspects of the concept "responsibility" in works by foreign researchers. Perspectives of research and development: Collection of scientific articles. SAUL Publishing Ltd, Dublin, Ireland, 2017. P. 129-131. 